\title{
CONCRETOS REFRATÁRIOS PARA CONDIÇÕES OPERACIONAIS CRÍTICAS DE CANAIS DE CORRIDA DE ALTOS-FORNOS*
}

\section{Resumo}

Vitor Guarnier Domiciano ${ }^{1}$ Aloísio Simões Ribeiro ${ }^{2}$ Rogério Diogo Araújo ${ }^{3}$ Alexander Rabello Ollmann 4 Humberto Chiaretti Bassalo ${ }^{5}$ Modestino Alves de Moura Brito ${ }^{6}$

A necessidade de melhorar as propriedades dos refratários monolíticos para resistir às condições operacionais cada vez mais severas e instáveis das casas de corrida de Alto-Forno tem sido um grande desafio para os fornecedores de refratários de maneira a garantir a segurança dos canais de corrida e sua disponibilidade para operação. Este trabalho apresenta as propriedades de novos concretos refratários $\mathrm{Al}_{2} \mathrm{O}_{3}-\mathrm{SiC}-\mathrm{C}$ (aplicados por vibração ou bombeamento/projeção a úmido) desenvolvidos para resistir ao severo mecanismo de corrosão que ocorre na linha de gusa de canais principais e que exige constante atenção dos operadores das casas de corrida. Testes realizados com os novos concretos refratários em canais de corrida principais de diferentes Altos-Fornos de grande produtividade revelaram uma significativa diminuição da velocidade de desgaste do revestimento refratário na linha de gusa oferecendo uma condição operacional segura e confiável às casas de corrida.

Palavras-chave: Canal de corrida; Concreto refratário; Velocidade de desgaste; Resistência a corrosão.

\section{REFRACTORY CASTABLES FOR CRITICAL BLAST FURNACE MAIN RUNNER OPERATING CONDITIONS}

\section{Abstract}

The need to improve the monolithic refractories' properties to endure the increasingly severe and unstable Blast Furnace casthouse operating conditions has been a major challenge for refractory suppliers in order to guarantee the runner's safety and its availability for operation. This paper presents the properties of new $\mathrm{Al}_{2} \mathrm{O}_{3}-\mathrm{SiC}-\mathrm{C}$ refractory castables (installed by vibrating or pumping/shotcreting) developed to endure the severe corrosion mechanism that occurs at the main runners' metal line which constantly requires a special attention of casthouse operators. Field tests carried out in different large-scale production Blast Furnaces main runners revealed a significant decrease of refractory lining wear speed at the main runner metal line using the new refractory castables developed leading to a safe and reliable Blast Furnace casthouse operation.

Keywords: Main runner; Refractory castable; Wear speed; Corrosion resistance.

1 Engenheiro de Materiais, Mestre em Ciência e Engenharia de Materiais, Pesquisador, Magnesita Refratários S/A.

2 Membro da ABM, Engenheiro Metalurgista, Mestre em Engenharia de Materiais, Assistente Técnico, Magnesita Refratários S/A.

3 Técnico Metalurgista e Siderurgia, Assistente Técnico, Magnesita Refratários S/A.

4 Engenheiro Metalurgista. Especialista da Área de Redução, Magnesita Refratários S/A.

Membro da ABM, Engenheiro Metalurgista e MSc. em Engenharia Cerâmica. Consultor.

6 Engenheiro Metalurgista e MSc. em Engenharia Cerâmica, Diretor Técnico de P\&D, Magnesita Refratários S/A. 


\section{INTRODUCTION}

In recent years, the Brazilian Ironmaking scenario has experienced major changes as a result of the huge competition in the global steel market and the shortage of high grade iron ore deposits and coke. In Blast Furnaces, the use of economically competitive raw materials (iron ore, coke, alternative fuels, etc) has allowed a better management of total production costs of hot metal. In the meantime, frequent oscillations in the Blast Furnaces operating conditions (production, casting temperature, slag-rate, slag composition, etc) has been noticed, which has shown a direct impact on the refractories' performance (castables, ramming mixes, taphole clays, etc) used in the casthouses [1-5]. Besides increasing refractory consumption, a dramatically change in the main runner wear profile was observed in some Blast Furnace casthouses leading to an unsafe casting operation mostly because of a remarkable increase of the refractory lining wear speed at the metal line [4-8]. In order to guarantee the main runner's safety and its availability for operation, new refractory castables were designed to endure the severe and unstable operating conditions that runners are facing in today's Blast Furnace casthouses' scenario.

This paper presents the properties of new main runner $\mathrm{Al}_{2} \mathrm{O}_{3}-\mathrm{SiC}-\mathrm{C}$ refractory castables (installed by vibrating or pumping/shotcreting) developed to meet these demands. The goal was to improve the castables' corrosion resistance at the metal line (slag-metal interface) without harming slag line performance. Field tests were carried out along almost one year in different large-scale production Blast Furnaces main runners in order to evaluate the refractory lining wear speed at both metal line and slag line and compare their performances with standard products.

\section{MATERIALS AND METHODS}

Ultra-low cement containing $\mathrm{Al}_{2} \mathrm{O}_{3}-\mathrm{SiC}-\mathrm{C}$ refractory castables (VFC = vibra-flow castable; $\mathrm{SFC}=$ self-flow castable installed by pumping/shotcreting) commonly used in large-scale production Blast Furnace main runners were considered as reference basis (standard products, also ULCC) for the development of new refractory castables. Samples of $230 \times 60 \times 60 \mathrm{~mm}$ were used to determine the main physical properties of the castables after different thermal treatments $\left(110^{\circ} \mathrm{C} / 24 \mathrm{~h}\right.$ and $1400^{\circ} \mathrm{C} / 5 \mathrm{~h}$ - coke breeze): apparent porosity (AP), bulk density (BD), cold crushing strength (CCS) and hot modulus of rupture (HMOR $\left.-1485^{\circ} \mathrm{C} / 3 \mathrm{~h}\right)$. The thermal shock resistance was evaluated by determining the residual elastic modulus $(E \%)$ of $230 \times 60 \times 60 \mathrm{~mm}$ samples after $0,1,3$ and 5 thermal shock cycles $\left(1200^{\circ} \mathrm{C} / 30 \mathrm{~min} \leftrightarrows\right.$ air). The oxidation resistance was evaluated by measuring the oxidized area on the cross section surface of samples after thermal shock test. The corrosion resistance tests were carried out in an induction furnace (IFT- $1600^{\circ} \mathrm{C} / 4 \mathrm{~h}$ ) and rotary drum furnace (RDT- $1650^{\circ} \mathrm{C} / 4 \mathrm{~h}$ ). The IFT is commonly employed to evaluate the castable's corrosion resistance at the main runner's metal line (slag-metal interface) and the RDT at the slag line (slag-air interface). The total amount of slag used in a standard corrosion test $(1600 \mathrm{~g})$ was increased $50 \mathrm{wt} \%$ (2400g) by enhancing the frequency of granulated Blast Furnace slag addition: Test $1(200 \mathrm{~g} / 30 \mathrm{~min})$ and Test 2 (200g/20min). The residual thickness (\%) of 2 prismatic samples was considered to evaluate the corrosion resistance of the standard VFC and SFC and the new castables developed. 


\section{RESULTS AND DISCUSSION}

The main guidelines which headed the development of the new refractory castables' formulations are presented in Table 1. The challenge was to improve the corrosion resistance and also obtain a good thermal shock and oxidation resistances. The new vibra-flow castable (VFC) particle size distribution (PSD) was completely modified and the total amount of alumina $\left(\mathrm{Al}_{2} \mathrm{O}_{3}\right)$ was increased. More coarse grains and higher top-size particle were introduced in the formulation. The silicon carbide (SiC) particle size distribution was optimized and its total amount was decreased. A new carbon $(C)$ source with higher oxidation resistance was introduced in the formulation and special attention was given to reduce the amount of raw materials which generate low melting point phases at high temperature. Similar adjusts were carried out in the new self-flow castable (SFC) formulation and its PSD was carefully improved in order to obtain a suitable rheology for pumping and shotcreting installations. Table 2 presents the refractory castables' main properties.

Table 1. Guidelines for the development of new refractory castable formulations

\begin{tabular}{|c|c|}
\hline Standard Product & GOAL \\
\hline $\mathrm{Al}_{2} \mathrm{O}_{3}$ & \multirow{3}{*}{$\begin{array}{l}\text { Improve corrosion, thermal shock and } \\
\text { oxidation resistances }\end{array}$} \\
\hline SiC & \\
\hline C & \\
\hline Others & Decr \\
\hline
\end{tabular}

Table 2. Main properties of the standard and new refractory castables

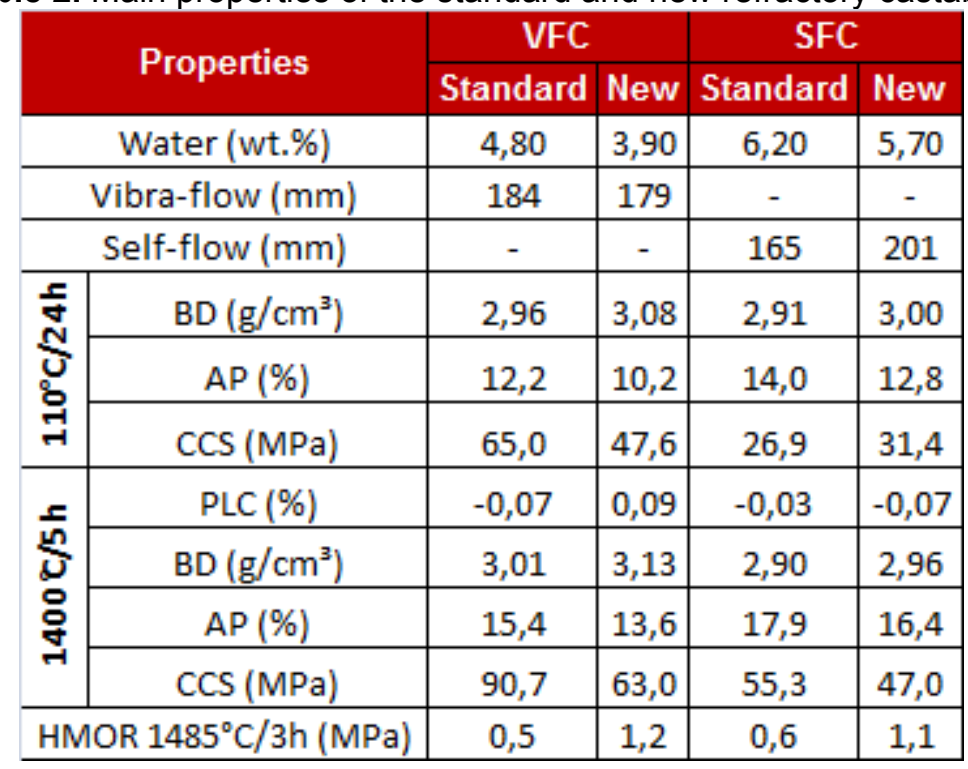

When compared to the standard VFC, almost 1.0 wt.\% less water was necessary to give the new VFC suitable flowability for installation (Table II). The physical properties revealed a lower porosity (AP) and higher density (BD) material which also show lower mechanical strength after different thermal treatments. In spite of the lower cold crushing strength (CCS), the new VFC castable exhibits higher hot modulus of rupture (HMOR). For the new SFC, a significant increase in flowability was obtained using $0.5 \mathrm{wt} \%$ less water when compared to the standard SFC. Lower porosity and higher density values were also verified but similar cold crushing 
strength was observed after different thermal treatments. The HMOR was also improved.

Thermal shock resistance (Figure 1) was evaluated by measuring the degree of loss of the elastic modulus ( $E \%)$ after different thermal shock cycles. The results revealed a slightly lower decreased of $E$ in the new VFC after 5 thermal shock cycles. This suggests that the main adjusts carried out in the new material resulted in less damage when compared to the standard VFC. For the new SFC, no significant difference was observed in the $E$ after the thermal shock test.

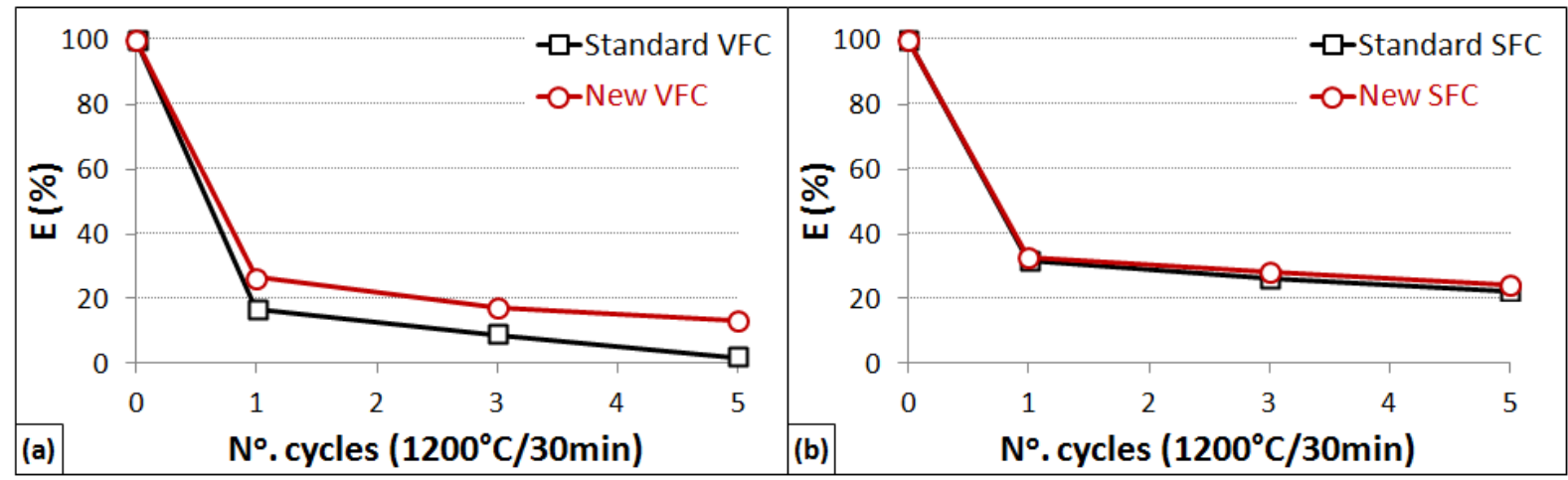

Figure 1: Thermal shock resistance: (a) VFC and (b) SFC.

Cross sections of samples after thermal shock test were used to evaluate the castables' oxidation resistance. The average oxidized area (\%) revealed a lower degree of oxidation in both new VFC and SFC (Figure 2).

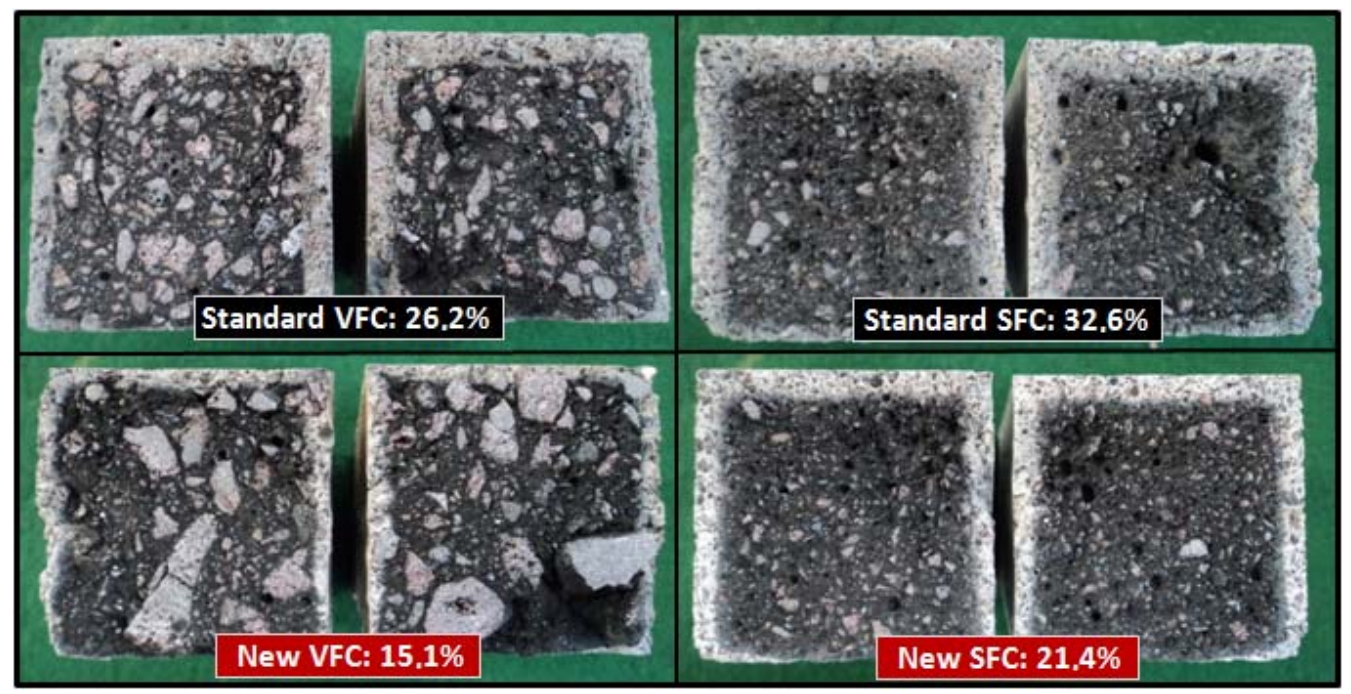

Figure 2: Cross section of castables' samples showing the oxidized area (\%).

In order to try to reproduce in lab tests the conditions that some main runners are operating nowadays and evaluate their effects in the refractory corrosion behavior, the Blast Furnace slag content used in a standard corrosion test (Test 1) was increased 50wt.\% (Test 2). The results revealed that both standard products (VFC and SFC) and the respective new refractory castables suffered with the increase of the amount of slag in the Test 2 and an increase in the corrosion wear (\%) was observed when compared to Test 1 (Figure 3). The tests carried out showed that even in a more severe test condition the new VFC developed exhibits a significant lower corrosion wear in both IFT and RDT (Figure $3 a$ and $3 b$, respectively), which 
suggests a significant improvement of the castable's corrosion resistance in both metal line (ML) and slag line (SL) zones of the main runners. For the new SFC, a lower corrosion wear was also observed after IFT (Test 2) when compared to standard SFC (Figure 4c). Nevertheless, similar results were verified in the RDT (Figure 3d). Such data suggested an improvement of the corrosion resistance in the main runner's ML but no significant change in the corrosion behavior at the SL. Figure 4 shows the castables' samples (VFC and SFC) after corrosion Test 2.
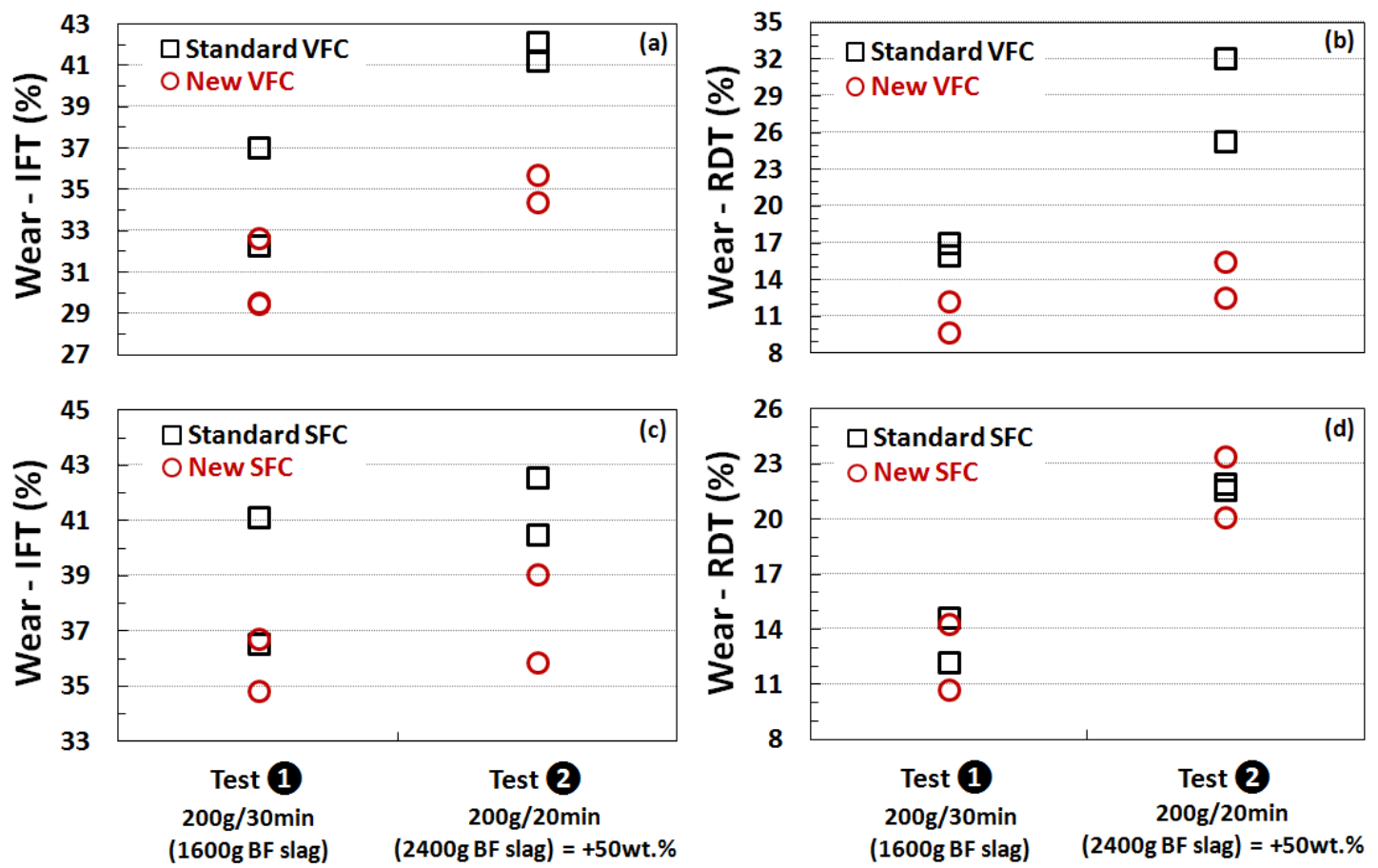

Figure 3: Corrosion resistance of the standard products and new castables: (a-c) Induction Furnace Test (IFT); (b-d) Rotary Drum Test (RDT).

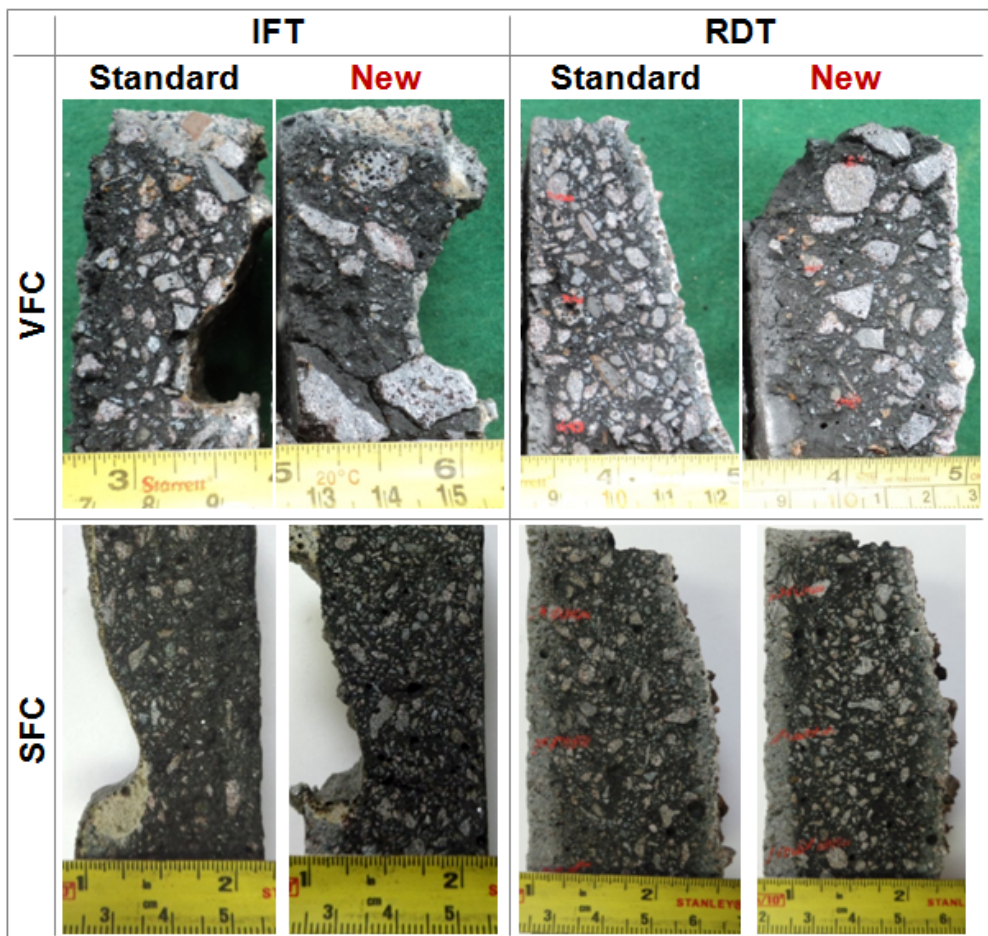

Figure 4: Refractory castables' samples (VFC and SFC) after corrosion Test 2 (IFT and RDT). 
Figure 5 shows the values of refractory lining wear speed of different Blast Furnaces' main runners using the standard VFC or SFC and the new castables developed.

The corrosion wear commonly observed in the main runner using the standard SFC always required an intermediate refractory lining repair in order to accomplish the 28 days of main runner campaign under safe casthouse operating conditions. The use of the new SFC revealed a decrease in the ML wear speed and a slightly increase of the SL wear speed when compared to the standard SFC (Figure 5a and 5b) though in different hot metal tonnage campaigns. Notwithstanding the difference in this comparison basis used to evaluate these results, the better performance exhibited by the new SFC enabled a continuous main runner operation and the intermediate refractory lining repair became no longer necessary to offer a safe and reliable casthouse operation along the 28 days of main runner campaign.

In the case of the VFCs, despite of no intermediate repair was required to accomplish the 28 days of main runner campaign using the standard product, the refractory lining frequently end up severely damaged and exhibiting evidences that was about to collapse at the ML along the turbulence zone [4,5,8]. The use of the new VFC revealed a significant decrease in the main runner wear speed at both $\mathrm{ML}$ and $\mathrm{SL}$ when compared to the standard product (Figure $5 \mathrm{c}$ and $5 \mathrm{~d}$ ). Besides offering safer operating conditions to the casthouse even under severe and unstable Blast Furnace operating conditions, the new VFC allowed a remarkable decrease in the main runner specific refractory consumption.

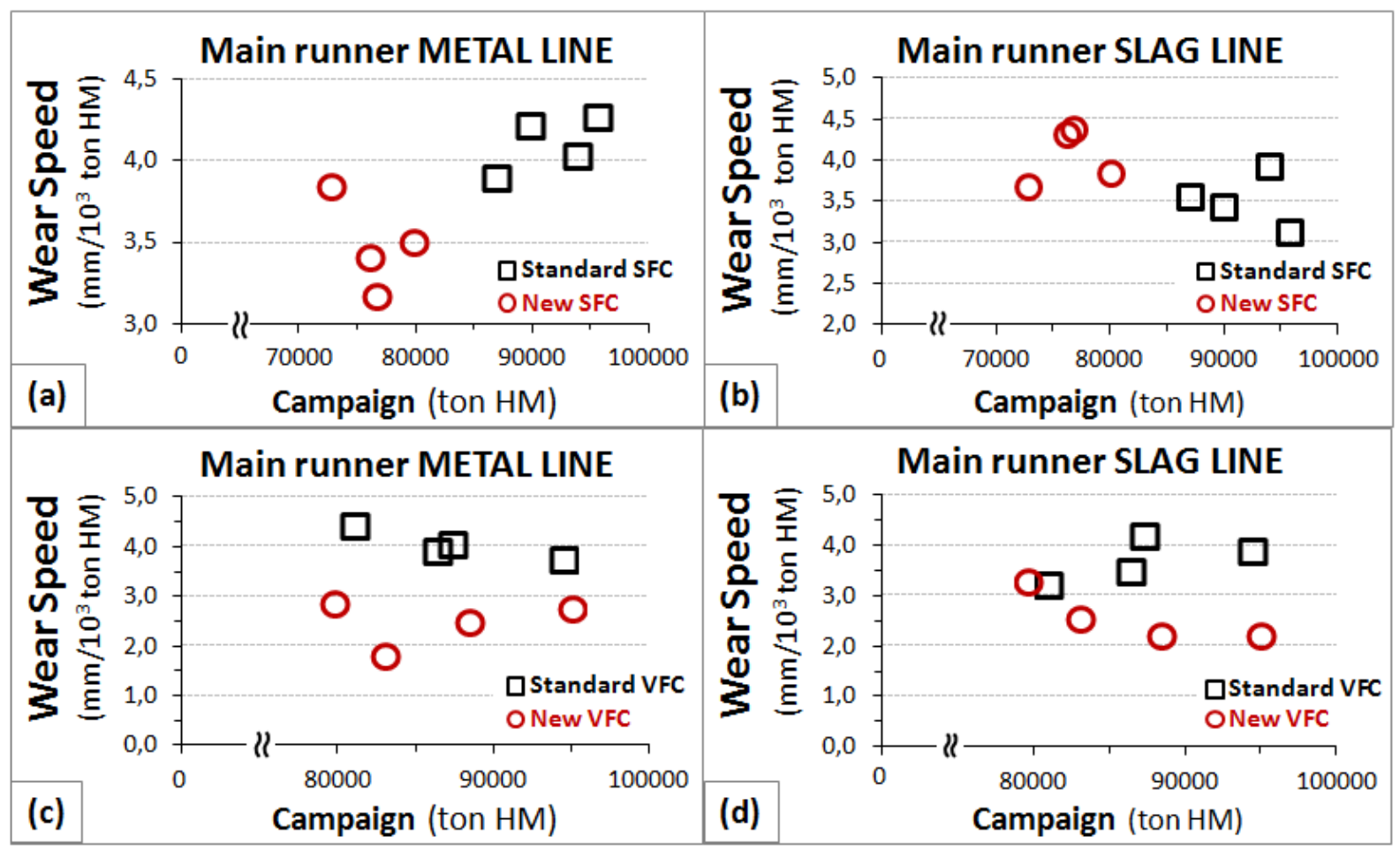

Figure 5: Refractory lining wear speed at the (a-c) metal line and (b-d) slag line by the end of the main runners' campaign.

\section{CONCLUSIONS}

The development of new refractory castables to endure the severe and unstable operating conditions that main runners are facing nowadays requires multiple adjusts in castable's formulation. The results obtained in different lab tests showed improved castables' properties which suggested potentially new products to be installed by 
vibrating or pumping/shotcreting. Field tests carried out along almost one year in different large-scale production Blast Furnaces main runners revealed a significant decrease of refractory lining wear speed at the main runner metal line using the new refractory castables developed leading to a safe and reliable Blast Furnace casthouse operation.

\section{REFERENCES}

1 YASUO, K.; KITAMURA, M.; IIDA, T. Effect of operating conditions on Blast Furnace trough ML castable deterioration. Shinagawa Technical Report, vol. 54, 15-24 (2011).

2 IIDA, M.; SUZUKI, K. Influence of Blast Furnace productivity on corrosion rate of main trough. Shinagawa Technical Report, vol. 54, 25-34 (2011).

3 IIDA, M. Effect of temperature on the dissolution of Al2O3-SiC-C castables in Blast Furnace slag. Journal of the Technical Association of Refractories, Japan, 32 [4] 271276 (2012).

4 DOMICIANO, V.G. et al. Influência dos teores de FeO e MnO da escória no desgaste de refratários de canais de corrida de Altos-Fornos. $40^{\circ}$ Seminário de Redução de Minério de Ferro e Matérias-Primas - 19 a 22 de setembro de 2010 - Belo Horizonte - MG Brasil.

5 DOMICIANO, V.G. et al. Does the MgO content of the Blast Furnace slag affect the performance of main troughs? - UNITECR 2009, Salvador, Brazil, paper 141.

6 YOSHITOMI, J. et al. Local corrosion of iron trough refractories in the slag-metal interface. Aachen Proceedings, p. 85-89, 1998.

7 IIDA, M.; MAEDA, E.; OKAMOTO T. Effect of SiC oxidization on corrosion resistance of castable for metal line of blast furnace main trough. Journal of the Technical Association of Refractories, Japan, 27 [2] 90-95 (2007).

8 DOMICIANO, V.G. et al. Desafios da ala de corrida de Altos-Fornos: Análise de falha de concreto refratário para canal de corrida. $43^{\circ}$ Seminário de Redução de Minério de Ferro e Matérias-Primas - 1 a 4 de setembro de 2013 - Belo Horizonte - MG - Brasil. 